\title{
赤外吸収スペクトル分析法の問題点
}

\section{田中城 之*}

\section{1 楮音}

赤外吸収スペクトル法（以下, 赤外法と略称する）の発洋は古 く,すでに 19 世紀末より 20 世紀始めの頃には，ある特定の官 能基を有する有機化合物は，すへてて一定の波長に赤外吸収を示す ことが発見されていたのであるが，実際に分析方法としての重要 性が注目されたしたのは, 第二次大戦前後, 電子管の進歩と共に, 各種のインストルメンテイションが著しく発展し，自動記録式の 装置が商品として発売されるようになってからである。それより また 20 年にみたないが，すでに，有機化合物を取扱 5 工場，研 究室はいわずもがな，無機化合物を対象とする所でさえも，かな り利用されるようになっている。赤外法に関する研究報告の review は, Analytical Chemistry の Annual Review や分析化 学進歩総説などにまとめられてはいるが，あまり多数なため到底 すべてのものの網羅はできない現状である。測定装置に関しても 最初は，研究用 1 種類しか作られていなかったものが，分化進展 し数年前の簡易型の発表によって佰温佰湿室以外でも手軽に利用 できるようになり，また，分散系として回折格子を使用する高分 解能型の装置により，従来よりさらに微少な波長差の検討も可能 となった。このような赤外法の発展の過程を, わが国に抽ける赤 外分光光度計の稼動状況の概数の推移とい5形で眺めることもで きるが，これを表 1 に示した。これよりわが国では現在 1000 台 以上の装置が稼動して，各種の測定を行なっていることが明らか であろ5。さらに，最近は，化学工場の日常分析に各種の自動連 続分析計が用いられるよ5になりつつあるが，後揭の総説にもあ るように，赤外ガス分析計も，その方面で重要な役割を演じてお り, わが国でも現在数 100 台が稼動中で, 各種の化学工場で利用 されつつある。このようにして, 赤外法は, これる最近めさまし い発展を示したガスクロマトグラフ法と並んで今や有機工業分析 法の双壁として押しも押されるせぬ地位を占めているわけである。

表 1 わが国に护ける赤外分光光度計棲動状況概数の推移

\begin{tabular}{|c|c|c|c|c|c|c|}
\hline 分 & 辎 & 1950年 & 1956年夏 & 1959年秋 & 1961年春 & 1962年秋 \\
\hline \multicolumn{2}{|c|}{ 外国品 } & 1 & 25 & 夵 55 & $\begin{array}{l}\text { 示 } 80 \\
20\end{array}$ & $\begin{array}{l}\text { 大 } 90 \\
\text { 吕 } 30\end{array}$ \\
\hline \multicolumn{2}{|r|}{ 日本分光 } & - & 5 & 大 30 & 夵 90 & 大 125 \\
\hline \multirow[t]{2}{*}{ 国庶 } & 津 & - & - & $\begin{array}{ll}\text { 态 } & 5\end{array}$ & $\begin{array}{l}\text { 大 } 30 \\
\text { 小 } 85\end{array}$ & $\begin{array}{r}40 \\
\text { 尔 } 180\end{array}$ \\
\hline & 日 立 & - & - & 夵 40 & $\begin{array}{ll}\text { 太 } 85 \\
\text { 小 } 15\end{array}$ & $\begin{array}{l}\text { 大 } 95 \\
\text { 小 } 120\end{array}$ \\
\hline 合 & at & 1 & 30 & $\begin{array}{r}\text { 大 } 130 \\
\text { 小 } 4\end{array}$ & $\begin{array}{l}\text { 大 } 285 \\
\text { 小 } 170\end{array}$ & $\begin{array}{l}\text { 大 } 355 \\
\text { 小 } 495\end{array}$ \\
\hline
\end{tabular}

工業分析的立場から赤外法の現状を眺めると, その問題点とし $\tau$,（1）適用限界，（2）定性分析関係，（3）定量分析関係， （4）自動連続分析法としての赤外ガス分析計に関する諸問題,

（5）近赤外, 遠赤外領域への拡張，（6）さらに, 他の機器分 析法などとの関連性の問題などが浮かび上がるが，（2），(4)， （5）については，このシンポジウムの別の所で議論される筈な

* 東京大学工学部工業化学教室 : 東京都交京区本富士町.
のでここでは割愛し，残りの（1)，（3）の点について，以下 に簡単に考察して行くこととする。

\section{2 適 用 限 界}

原理的にいえば，有機化合物はすべて赤外吸収を示し，気体， 液体, 溶液, 固体いずれの状態でも測定可能である。また，すべ ての有機物は人の指紋と同じように拈の括の固有のスペクトルを 示し, 従って, 対掌体の例外を除いては, 同定が可能である。さ らに, 官能基の分析もでき，全赤外領域中で適当な特性吸収を用 いれば，他の化合物との識別，構造決定，また分離定量が可能で ある。

しかし，実際問題としては，すべての有機工業分析の問題を， これで解決することはできない。それは，まず，実際に測定不可 能なものがあるといら試料調製上の面での制約のためであり，ま た，測定はできても，他成分の吸収との重複などにより，それか ら先の分析が不可能なものがあるためである。さらに, 以上のこ とが不可能でなくとも，かなり困難であり，後述のように，他の 方法による方がはるかに容易に解決できるという場合がしばしば ある。従って，この方法での適用限界を的確に把握して扰く必要 がある。

\section{$2 \cdot 1$ 試料睭製上の問題点}

赤外法の苦手とする水の問題もさることながら，試料調製上で 最も問題になるのは，固体に対する取扱い方法である。他の有機 機器分析法例えばガスクロマトグラフ法などでも，固体の取扱い が困難または不可能なものが多く, 赤外法は, 固体をそのまま測定 できる点ですぐれてはいるが，必らずしもすべての固体が測定可 能とは限らない。. 固体の取扱い方法の進歩をふりかえって見れば， はじめは Nujol 法, 溶液法, 薄膜法程度であったものが次第に 各種の調製方法の考案がなされ，現在最大の利用度をほこる $\mathrm{KBr}$ 法をはじめ,アルミニウムステアレート法, 機械的薄膜調製法, さらにマトリックス単離法など各種の測定法が提案され，またそ の定量的取扱い方法が研究され，利用されてきた。しかし，これ でもなお，極く最近までは，溶媒に不溶で，柔軟性，弾力性のあ る，細粉にならないようなものなど，かなりの種類の試料はなか なからまく測定ができない状態であった。

そこへ登場してきたのが, attenuated total reflection 法1)で ある。これは，反射スペクトル法の一種であるが，この言葉に相 当する適当な用語が現在わが国にはないので，筆者らは，これを 赤外全反射吸収スペクトル法2) と呼んでいる。この方法は現在発 展しつつある方法であり，簡単に説明すれば，試料の測定には反 射スペクトルの方法を利用しながら，しかもスペクトルは曼取ス ペクトルにあたるものが得られるという剖期的なるので, この方 法により従来の問題点の大半は解決されだしたここの方法の得意 とする応用範囲を概観すると次のようになる。

（1）不溶, 不融, 粉砕困難な弾性，粘性物質の測定が可能で 
ある。従って, 従来うまい測定法のなかった加硫ゴム, ウレタン ホーム，合成革，熱硬化性樹脂などの測定が容易となった。

（2）薄膜法で測定困難な物質の湘定が可能である。従って, それ以上薄くできない各種高分子の厚い膜あるいは板の测定がそ のままで可能となった。

（3）表面の極く薄い層だけを問題にし得ることも, 特徽の一 つであり，従来の透過法では，はがしてみなければならないため, 非常に面倒であった塗料の塗膜面, 種々のテープの表面, 色々な 表面加工物, 表面劣化試料など各種の測定が可能となった。

（4）含水試料の測定も可能である。従って, エマルジョン, 洗浄剤などの測定が可能である。

（5）入射角さえ一定にして甜けば，試料の厚みを考虑する必 要がない。従って, 以上の諸点より, 各種の試料の迅速分析, 工 程分析が行なえる。

（6）完全に非破壊で分析できる可能性がある。例えば動，植 物の生体細胞表面の測定, 美術品その他貴重な試料の鑑定が可能 である。

以上のように，試料調製法の進歩により，適用範囲の払張は着 々と行なわれて拈り, 特に赤外全反射吸収スペクトル法の進展に 従い, 赤外法の利点はいっそ弓発揮されるようになったが, しか しこの方法にも現在, 限界点ないしは未開発の分野がある。例え ば，この方法での最も重要な点の一つに，試料と高屈折率媒質※1 との接触の問題があり, 現在の所では, 試料は表面が平滑な板状 または薄膜状である必要がある。従って, 瀻維状のるの例えば布 の測定などは困難で，試料の形状による適用制限をかなり受けて いる。また，定量的取扱いの部分に関しても不十分の点があり， さらに研究をする必要がある。

このように, 試料調製の点で, 以前と比較すると, はるかに広 範囲に赤外法の適用ができるようになってきつつはあるが，な拉 一部には, 適用限界があり, 試料調製法のさらに高度の研究が望 まれている。

\section{$2 \cdot 2$ 他成分の吸収との重複の問遉}

すべての有機物が赤外域に吸収を示すことは, 赤外法の利点で はあるが, 逆に他成分の吸収と重複する可能性が生じ, 甚だしく 重複する時は, その判別が不可能となってしまう。この点は, 化 合物すへてで必らずしも吸収を示さないという久点を持ちながら， 逆にこれが利用されて，吸収を示さない大量成分中の，吸収を持 つ微量成分の検知を得意とする紫外吸収法と対照的である。分析 化学に打いては, 利点は欠点, 欠点は利点なりといらことによく 遭遇するものであるが，これもその一例である。

さて, 他成分の吸収と重複があるとすれば，どの程度他成分が 混入していても分析可能であるかという点が最す実際的問題であ るが,これは, 場合場合により, その特性吸収の重複の程度が違 うので，実情に応じて考えなければならない。一般に，数成分以 上の多成分系になると, 各成分の検知が難しくなり, 特に定量分 析の場合, 定量値の誤差が大きくなってしま5傾向がある。この 点が, 赤外法がいかなる問題に対しても万能にならない最大の要 因の一つである。例えば, 脂肪族飽和炭化水素の多成分混合物中 に含まれているカルボニル化合物など, 共存成分中にない異種官 能基の吸収を利用する分析は，赤外法の得意とする所であるが, 共存成分である脂肪族飽和炭化水素混合物の各成分の各個定量を ※1この部分の詳細は文献 2) を参照されたい。
行なおうとしても，C-H にもとつくく主な吸収は皆同じように現 われてしまうので, 他成分と重複しがちな弱い吸収しかキイバン ドとして利用できず，精度のよい定量分析など到底望むべくもな いことは明らかである。従って，石油中に含有される炭化水素成 分の分析などには，そのまま赤外法を適用することは不適当であ る。また，芳香族異性体の分離定性定量は，赤外法の特徽的用逯 の一つであるが，この時でさえも，成分数が多くなると，各特性 吸収が重複してしまい, 判別困難となる。従って、コールタール 留分にしても，蒸留により，ある程度沸点範囲を区切ってから分 析を行なわねばならないものもある。

このように，赤外法により，多数の成分を含む試料の分析を行 な括うとする際には，その実情に即して，抽出，蒸留その他各種 の前処理により，成分数をある程度以下に減じてから，分析する ことを考えねばならないが，この操作が簡単に行かない時には， 多成分混合していても，それ程困らないガスクロマトグラフ法な ど他の機器分析方法の適用を考えるべきである。

\section{$2 \cdot 3$ その他の問題点}

上記のほか, 未知物質の構造決定の際など, 赤外法のみの知見 では判定ができない場合，定量分析を行な和うとしても標準物質 が得られない場合など色々な限界があり，他の機器法との併用を 必要としたり，また，特別の処理法を必要としたりするが，これ に関しては, 他の総説や次項で触れるのでここでは省略した。

\section{3 定量的取扱いの際の諸問題}

赤外法で定量的取扱いをする場合の基礎は，可視紫外吸収スペ クトル法と同様 Lambert-Beer の法則である。従って，その成 立する範囲内で，標準物質を用いて検量線を作成し，定量すれば よい。赤外法ではこの通常法から出発し, 補償法, グループタイ プアナリシスなど各種の定量が可能である。定量的取扱いをする 時は, 溶液状態で行ならのが最も望ましい。しかし,なかなかそ ろできない試料も多くあり，これに対処すべく，特に，種々の固 体状での定量的取扱いについては, 従来からかなりの研究が行な われて特り, 着々と問題が解決されてきた。ここでは紙数の関係 から,これら進歩の過程や個々の問題点についてはふれず, 現在 定量的取扱いを行なう際に，考えておかねばならない点など一般 的なことのみについて簡単に述べることとする。

\section{$3 \cdot 1$ 定量值の精度, 正確さ}

何成分系かの定量分析を行なった際，その定量值の精度は，そ れらの成分数, 重複の程度などにより左右されるので, 一概には いえないが，一般に，測定值の $1 \sim 5 \%$ 程度の誤差は考える必要 がある。まれに，例えば $90 \%$ 程度の純度のものを通常法により $0.1 \%$ 位の精度で分析できたというような報告も見受けたことが あるが，これは，かりに吸光度 0.5 の付近の測定とした時の精 度が約 0.0005 すなわち透過率約 32\% の吸収を $0.03 \%$ の透過 率精度で測定できることを意味し，普通の装置ではもち論そこま での能力はないから，このよ5なことがいつも起こるとは到底考 えられない。最近，透過率拡大装置が取付けられるよ5になって きたが，これも，従来精度の悪かった少量成分の定量值の相対精 度の向上には有効であると考えられるけれども，大量成分の定量 值の場合には，さほど効果が期待できない。従って，赤外法によ り，何か工程分析をするような場合，その值の精度に対し，不当 に厳しい要求は出すべきではなく，もし，その要求が絶対必要の 


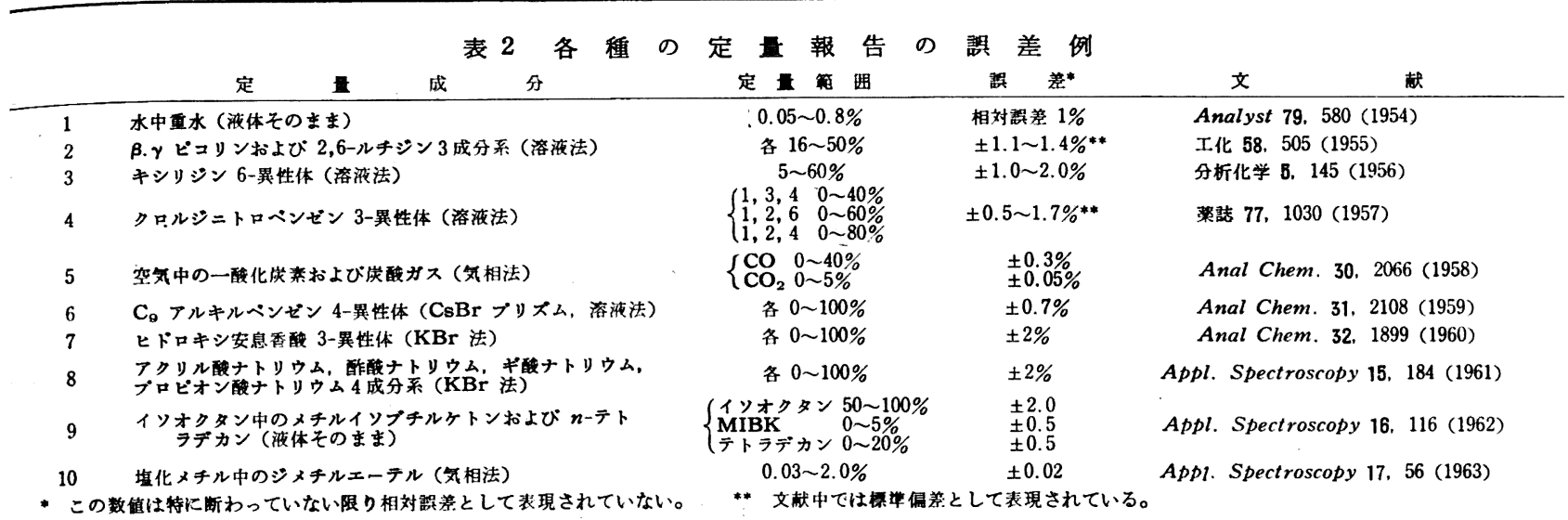

ものならば，何らかの別の方法によることを考えるべきである。

また，分析方法に問題があると，分析值に偏りを示すことがあ るから，工程分析などの際には，あらかじめ標準混合試料を作製 して，それを検量線を用いて定量し，定量值の精度および正確さ の検定をしておくとよい。

検量線についても，一度作れば，あとはいつでもそれを利用し てよいかどうかの問題がある。装置の感度の日間変動を長期間検 討したデータの発表はあまりなく，また装置の性能によっても左 右されるが，当研究室の経験では，測定值に対し少なくとも $2 \%$ 程度のバラッキは覚悟せねばならないという結果を得ている。従 って, それ以内の精度で定量值を得る必要がある時には, 必らず 毎日検量線を作らねばならない。

表 2 に従来報告された定量例の誤差のいくつかを示す。

\section{$3 \cdot 2$ 検知限度}

赤外法は, 他の機器法に比し, 徽量成分の検知定量は不得意で ある。これは，多かれ少なかれ，他の大量成分の吸収が重複して しま5ためで，具合の悪い時には $1 \%$ 程度，一般に $0.1 \%$ 程度， 都合がくても $0.01 \%$ 程度の検知限度しかない。なお, 検知限 度の定義は色々あるが，ここでは，その微量成分によって1\%の 透過率変化を生じる濃度をいうこととする。

検知限度を求めるような場合には，一般に補償法を用いるが， その際は，次の注意が必要である。ます，最適補㑽濃度 ${ }^{3)}$ を決定 する。詳細は省略するが, これは, ある程度以上補償溶液の濃度 をヒげなければ，補償法の効果を発揮することができないし，ま た濃度を上げすぎて，ある程度以上，試料光路および補償光路を 通過した光量がなくなれば，感度が悪くなり，かえって検知限度 が悪くなるためで，一般の装置では，問題の波長で 20〜 40\% 透 過率を示す程度の濃度が最適である。この祩，条件が許せば，ス リット幅をひろげた方がよい。最適補償淟度が決定できれば，あ とは常法通り検量線を作成し, これより検知限度が決定できる。

なお，前頃で触れた透過率拆大装置は，検知限度の向上に効果 的ではらるが，大局から見て，他の機器法と比較した場合の検知 限度に関する赤外法の立場の悪さを根本的に改善するるのではな い。従って，それ以上の微量を定量する必要のある場合には，あ らかじめ何等かの方法で漫縮したものを取扱らか, または他の機 器法にのりかえるかせねばならない。

\section{3 代用標準物稓法特に文献值借用の場合の問題}

赤外法の特徵の一つは, グループタイプアナリシスができるこ とである。これは, 各種の官能基の特性吸収は, その波長位置が ほぼ一定しているばかりでなく，またその官能基 1 個当りの吸光
係数も，類似物質の場合には，だいたい一定していることを利用 して，各種の定量をするものであるが，この方法によれば，例え ば通常法で定量しようとしても，定量に必要な標準物質が得られ ないときに，その類似同族体を代用して，含有量を推定すること もできる。また, 未知物質中の官能基の数を, 同一官能基を有す る類似化合物の特性吸収強度と比較して決定することもできる。 これらの分析例は数多く報告されており, 赤外法の利用度をさら に大きなるのにしているが，代用標準物質としては，その同族体 列で，なるへく類似している化合物を用いるべきである。類似性 が悪くなればなるほど, 問題の物質の分子吸光係数との差が大き くなり，誤差の原因となる。

この際，もし代用標準物質も全然入手できない場合はどうなる であろうか。そうなれば他の文献値を借用せねばならない。しか し, 赤外吸収スペクトルに怙いてはスリット幅と吸収帯の幅とが 同程度であるため, 吸光係数が各装置の性能によって支配される ので, 他の装置で得た吸光係数値を, そのまま, 無批判に借用す ることはできない。そこで, 器差による值のかたよりの心配もな く，文献值の利用による定量分析ができるためには，いかなる装 直であっても，なるべく一定の值が得られるよ5な何らかの強度 測定法により，吸収強度を求める必要があるが，この対策として 現在，次の二通りの方法が行なわれている。

（1）頂点強度比法 もし, 一連の吸光係数值が文献に記載さ れていて，そのいくつかの標準物質は手許にある場合，この方法 によるのが一番簡便である。すなわち， 2 種の分光光度計で測定 された同一試料の吸収強度の間には，一般に比例関係がほほ成立 していると見てょいから，手許にある標準物質の吸光係数值と対 応する文献値より，2 種の装直による見かけの強度比がわかる。 従って標準物質がなくても，それを手許の装置で測定した時に得 られる吸収強度は, 文献值の計算により, かなり正確に得ること ができる。筆者らの検討結果)によれば，単に物質の分子吸光係 数のみを，種々の型の 装置十数台を用いて比べた時には，10\% 以上のバラッキが見られたものが，2 種の標準物質の比の形にし て比較すると, ハララッキは5\%以下に小さくなった。この方法は もし，各成分量の比のみに言及する場合であれば，さらに広範囲 の応用ができる。すなわち，手許に全然標準物質がなくとも，キ イバンドにおいて互いに他成分の重䙓がないとい5仮定さえみた されるならば，文献記载の両者（または三者以上でも可）の強度 比をそのまま利用して，両者の存在比を簡単に計算することがで きる。また他成分の重複があった場合には，連立方程式の各俰数 が文献で与えられていさえすれば，その解から各成分の存在比を 
ければ,この問題は，すでに半分以上片付いたといっても過言で はないであろち。

従って, 実際問題としては, 各機器分析法などの長所短所をよ く知って, 最も有効に利用することが必要である。各種機器分析 法の比較は，色々されているが，普通一覧表の形でまとめたすの が発表されている。これらの表には，一般的な事項しか記載され て括らず，個々の問題には，表以外の知識を総合した利用者の的 確な判断を必要とする場合るあるが，一目で種々の比較ができる 便利なものである。ここでも，各種の比較を詳細に述べる紙数が ないので, その一例7) から引用し, 表 3 亿主要有機機器分析法 5 種を選び，それらの比較を示して㧍く。

\section{5 結}

以上，工業分析的立場より見た赤外法の問題点を，他の総説と 重複しないように, 簡単に述べて来たが, 赤外法の応用の際, 心 すべきことややはり（4）で述べた点であろう。

赤外法は, 有機機器分析法として, 最も利用度の高いものの一
つではあるが，分析的な意味で，その全能力を発揮できるのは， 他の機器法などとの関連性を考虑して, 最適の応用をした場合の みである。

従って, 赤外法により何かを分析しょうとされる方々は, 同時 に, 他の機器法などの長短に関しても，よく理解された上で, 常 にそれらの5ちでの最適機器法の選択または併用を，臨機応変に 考慮されながら，効率よく分析されることを望んで，この稿を終 ることとする。

$$
\text { 一文 献一 }
$$

1) J. Fahrenfort, Spectrochim. Acta 17, 698 (1961) など.

2). 田中, 川端, 二瓶, 鎌田, 工化 66, 1571 (1963).

3) 鎌田, 田中, 林原, 分析化学 4, 545 (1955).

4) 田中, 他 17 名, 工化 66, 1567 (1963).

5) E. B. Wilson, Jr., A. J. Wells, J. Chem. Phys. 14, 578 (1946).

6) D. A. Ramsay, J. Am. Chem. Soc. 74, 72 (1952).

7）鎌田, 仁木, 田中, 土屋, 高橋, 化学工場 6,2 号, 34 (1962).

\section{赤外定性分析とスペクトルデータ集}

\section{佐 伯 慎之 助*}

赤外吸収スペクトルが原理的に分析に応用しうることはかなり 古くからわかっていたが, 戦前は主として装置の不備のために再 現性のあるスペクトルを測定することが困難であり，そのため分 析に用いられた例はほとんどなかった。しかし前大戦中，有機物 の迅速な分析法に対する要望が高くなったので，米国においては 赤外分光計の技術的開発が強く推進され，その成功によって赤外 吸収スペクトル分析の一応の基礎が確立された。さらに戦後に至 って種々の技術の進歩に伴って, 赤外分光計る飛羅的発展を重ね, 現在では化学分析の強力な一手段としてなくてはならぬ存在とな り，活発に各方面で用いられていることは周知の事実である。

赤外吸収スペクトル分析は現今では極めて広範囲に，かつ頻繁 に用いられている分析法であるが，しかし見方によってはその方 法が必ずしも完全に確立しているとはいえないようである。その 点を考慮するために従来, ないしは現在普通に行なわれている赤 外定性分析法をふりかえってみよう。

従来, および現在一般に行なわれている赤外定性分析法の手順 は次のようなものである。

a. 測定されたスペクトルから，特性吸収帯の知識をるとにし て官能基を推定する。

b. 試料の物理的, 化学的性質をしらべる。例えば色, 匂い, 比重, 沸点, 融点, 屈折率, 元素分析の結果等である。さらに要 すれば試料の出所, 来歴等もしらべる。

c. a および b の知見をもとにして，考元 5 るいくつかの物 質を推定する。

\footnotetext{
* 東京工業試験所：東京都沿谷区本町.
}

d. 推定された物質のスペクトル（手許になければ新たに測定 する必要がある）を測定された未知試料のスペクトルと突き合わ せ，一致するかどうかをしらべる。

おおむね以上の四つの段階をへて定性分析が行なわれるのが通 常のやり方であろ5。

しかしよく考えてみるとこのようなやり方にはいくつかの問題 が含まれている。まずaの方法を行ならためには特性吸收帯に関 する詳細な知識が必要である。もちろんコルサップの表などとい うものがあって，かなり広く用いられているようであるが，この 表はたた機械的に用いるだけでは，あまり多くの知見を得られる ものではなく，ほとんどの場合明確な結論には到達できないとい らことは，多少なりともこの表を用いた経験をるつ人にはよく知 られていることである。この表, もしくはこれと類似の特性吸収 帯の表を用いて，正しい結論に到達するためには，赤外吸収スぺ クトルに関する基本的知識と豊富な経験とが必要であり，それが 不足していては結論が得られないたけけてなく，時には誤った結論 に導かれるおそれさ充ある。こように特性吸収帯表とい5すの は一見極めて有用なよ5に見光ながら，実際に用いてみるとそれ ほど有用ではないのであり，たとえ正しく使用してもそれから得 られる結論は殆んど常に一義的な結論ではなく，上記 $\mathrm{b}$ の段階を 経た後もな持未知試料の範囲を限定し5るにすぎないか，あるい はせいぜい $3 ， 4$ 種類の化合物が候補として得られるにすぎない。

そこで当然 $\mathrm{d}$ の段階が必要となる。未知試料のスペクトルを既 知物質のスペクトルと直接比較照合するとき，末知試料が既知物 質と同一物ならばそのスペクトルはびったりと一致する。その一 